\title{
ANALISIS KINERJA KARYAWAN STUDI KASUS PT. REYCOM DOKUMEN SOLUSI
}

\author{
Mujibul Hakim ${ }^{1)}$, M. Rudi Fanani' ${ }^{2}$ \\ Teknologi Informasi \\ Institut Teknologi Dan Sains Nahdlatul Ulama Pekalongan ${ }^{1), 2)}$ \\ Email : Mujibul_hakim@hotmail.com ${ }^{1)}$ \\ M.Rudifanani@ymail.com ${ }^{2)}$
}

\section{Katakunci: Abstrak:}

Kinerja, Penelitian ini bertujuan mendeskripsikan kinerja karyawan yang berada di Kompensasi, PT. Reycom Dokumen Solusi, kinerja karyawan terbilang masih rendah Motivasi didukung hasil penelitian. Penelitian ini merupakan penelitian deskriptif kualitatif, subjek penelitian ini adalah karyawan PT. Reycom Dokumen Solusi. Pengumpulan data dilakukan dengan teknik observasi, wawancara, dan survey. Keabsahan data yang dilakukan dengan triangulasi teknik dan sumber. Teknik analisis data menggunakan teknik analisis deskriptif kualitatif. Hasil penelitian ini menunjukkan kinerja yang baik karena dipengaruhi oleh beberapa faktor. Adapun faktor-faktor yang mempengaruhi di antara nya adalah adanya faktor eksternal, kompensasi dan motivasi terhadap kinerja karyawan. Implikasi manajerial dari penelitian ini adalahPenempatan SDM, disiplin kerja, target produksi, kepuasan kerja, motivasi, kompensasi, sistem manajemen, bonus/insentif, tunjangan kesehatan, tunjangan keluarga, pensiun, transport dan fasilitas kantor belum mampu meningkatkan kinerja karyawan.Manajerial seharusnya melakukan evaluasi untuk meningkatkan kinerja karyawan pada PT. Reycom Dokumen Solusi.

Keywords:

Performance,

Compensation,

Motivation

\section{Abstract:}

This study aims to describe the performance of employees who are at PT. Reycom Document Solutions, employee performance is still relatively low supported by research results. This research is a qualitative descriptive study, the subjects of this study are employees of PT. Reycom Document Solutions. Data collection is done by observation, interview and survey techniques. The validity of the data is done by triangulation of techniques and sources. Data analysis techniques using qualitative descriptive analysis techniques. The results of this study show good performance because it is influenced by several factors. The influencing factors are external factors, compensation and motivation for employee performance. Managerial implications of this research are HR Placement, work discipline, production targets, job satisfaction, motivation, compensation, management systems, bonuses / incentives, health benefits, family benefits, pensions, transportation and office facilities that have not been able to improve employee performance. Managerial should conduct an evaluation to improve employee performance at PT. Reycom Document Solutions. 


\section{PENDAHULUAN}

Sebuah perusahaan selalu berusaha menemukan cara dan kebijakan yang efektif untuk dapat meningkatkan suatu kualitas dan kuantitas. Persaingan perusahaan jasa di negara Indonesia semakin pesat, oleh karena itu maka PT. Reycom Dokumen Solusi (RDS) di negara Indonesia berkomitmen untuk berperan aktif dalam persaingan tersebut. PT. RDS bergerak pada layanan jasa yang fokus pada manajemen dokumen yang menyediakan End to Endlayanan dari document imaging, data capture, verifikasi telepon dan percetakan untuk Keuangan, Telekomunikasi dan Industri Asuransi. Berperan aktif dalam layanan jasa di negara Indonesia harus ditunjang melalui kinerja perusahaan dan kinerja perusahaan yang baik dibentuk melalui kinerja karyawan, karena karyawan adalah tumpuan utama organisasi atau perusahaan.

Karyawan adalah ujung tombak dalam kemajuan perusahaan, karena itu Tabel 1. Tabel Target Project kemajuan dan kemunduran suatu perusahaan tergantung pada kinerja karyawan. Kinerja yang buruk akan berakibat pada minimnya produktivitas karyawan dalam perusahaan. Perusahaan membutuhkan karyawan yang mampu bekerja dengan lebih baik dan cepat, sehingga diperlukan karyawan yang mempunyai kinerja (job performance) tinggi (Satria Tahir, 2013). Faktor penting yang dapat menentukan kinerja karyawan dan kemampuan suatu organisasi beradaptasi dengan lingkungan menurut Bass et al (2003) adalah disiplin, motivasi, dan prestasi kerja.

Permasalahan kinerjapun menjadi fenomena yang sangat menarik utnuk diangkat karena menurut Hasibuan (2001) kinerja yang buruk berakibat pada pencapaian waktu yang menurun dalam perusahaan. Oleh karena itu dapat kita lihat pada tabel 1.1 bagaimana tingkat target project pada PT RDS.

\begin{tabular}{|c|c|c|c|c|}
\hline No & Devisi & Bulan & Target Project & Selesai Project \\
\hline 1 & Binding Manual & Juni - September & 10 Hari & 14 Hari \\
\hline 2 & Binding Mesin & Juni - September & 8 Hari & 11 Hari \\
\hline
\end{tabular}

Sumber: Pt. Reycom Dokumen Solusi

Pada tabel diatas yang diambil dari target project pada bulan Juni sampai September 2015 terlihat fenomena bahwa ketepatan waktu suatu project menurun dapat kita simpulkan bahwa menurunya ketepatan waktu akibat dari menurunya 
kinerja karyawan. Ini sesuai dengan teori yang dikemukakan Hasibuan (2001) kinerja merupakan capaian hasil kerja seseorang dalam melaksanakan tugas pekerjaan yang dibebankan kepadanya berdasarkan atas kesungguhan, kecakapan, waktu dan pengalaman. Sehingga dapat kita simpulkan secara sederhana terdapat fenomena permasalahan kinerja pada PT. RDS.

Untuk meningkatkan kinerja karyawan, perusahaan tidak mengabaikan faktor kepuasan kerja karyawannya (Soegihartono 2012). Sutrisno (2007) mengemukakan motivasi dan lingkungan kerja menjadi prediktor utama dalam membentuk kepuasan kerja. Sehingga jika ada motivasi pada karyawan untuk melaksanakan tugas kerja dan lingkungan kerja yang mendukung satu sama lainya yang berpengaruh pada peningkatkan kepuasan kerja. Semakin tinggi motivasi ekstrinsik pegawai, maka tingkat kepuasan kerja karyawan akan semakin tinggi (Muslih 2011). lingkungan kerja dan upah secara simultan berpengaruh terhadap kepuasan kerja karyawan (Koesoemaningsih 2013). Kepuasan kerja karyawan yang tumbuh pada pekerjaanya saat ini dapat berakibat meningkatnya kinerja karyawan.

Kompensasi yang terindikasi oleh tingginya gaji, insentif, tunjangan dan fasilitas, maka akan semakin tinggi pula kepuasan kerja dan kinerja karyawan (Riansari, Sudiro \& Rofiati 2012). Pada teori kompensasi Hasibuan (2005) kompensasi menjadi faktor utama dalam membentuk kepuasan kerja dan kinerja karyawan. Tetapi untuk pengaruh langsung kompensasi karyawan terhadap kinerja tidak begitu kuat karena kompensasi dijelaskan Hasibuan (2005) mengutamakan kompensasi menjadi menjadi faktor yang membentuk kepuasan kerja dan kepuasan kerja berpengaruh pada kinerja karyawan. Jadi dapat disimpulkan secara sederhana pengaruh kompensasi terhadap kepuasan kerja yang dapat memberikan dampakya pada kinerja karyawan.

\section{TUJUAN PENELITIAN}

1. Menganalisis faktor eksternal yang dapat mempengaruhi Kinerja Kerja karyawan PT. Reycom Dokumen Solusi.

2. Menganalisis pengaruh Kompensasi terhadap Kinerja Kerja karyawan PT. Reycom Dokumen Solusi.

3. Menganalisis pengaruh Motivasi terhadap Kinerja Karyawan PT. Reycom Dokumen Solusi.

\section{TINJAUAN PUSTAKA}

a. Kinerja Karyawan 
Menurut Milner (1988), kinerja didefinisikan sebagai tingkat kebutuhan tiap individu, sebagai pengharapan atas pekerjaan suatu yang dilakukannya. Selain itu, Mangkunegara (2007) kinerja (prestasi kerja) merupakan hasil kerja secara kualitas maupun kuantitas yang mampu dicapai oleh seseorang dalam melaksanakan tugas sesuai tanggung jawab yang diberikan. Sedangkan Tim Studi Pembangunan Dalam Sistem Akuntabilitas Kinerja Instansi Pemerintah, Badan Pengawasan Keuangan dan Pembangunan (BPKP) (2000) mendefinisikan kinerja merupakan sebuah gambaran tingkat pencapaian yang dalam pelaksanaanya suatu dalam mewujudkan sasaran kegiatan/ program/kebijakan, tujuan, misi dan visi organisasi yang tertuang dalam perumusan perencanaan strategis (strategic planning) suatu organisasi. Penilaian kinerja adalah suatu sistem terstruktur dan formal untuk mengukur, mengevaluasi dan mempengaruhi atribut-atribut yang dapat berhubungan dengan pekerjaan, perilaku, dan outcomes karyawan, serta tingkat absensi, untuk mengetahui tingkat produktivitas dan efektivitas karyawan dalam melaksanakan pekerjaan di masa depan sehingga bermanfaat bagi karyawan, organisasi, dan masyarakat.
Secara lebih sederhana dapat dikemukakan bahwa penilaian kinerja merupakan suatu proses melalui organisasi dapat mengevaluasi atau menilai prestasi dari kerja karyawan Handoko (2001).

$$
\text { Mangkunegara }
$$

menjelaskan faktor-faktor yang dapat mempengaruhi capaian kinerja adalah faktor kemampuan (ability) yang terdiri dari kemampuan potensi (IQ) dan kemampuan reality (knowledge and skill). Selain itu juga terdapat faktor motivasi yang mampu membentuk suatu sikap (attitude) seorang pegawai untuk menghadapi situasi kerja. Oleh sebab itu, ada banyak factor-faktor yang dapat mempengaruhi tingkat kinerja karyawan, diantaranya faktor internal antara lain: kemampuan intelektualitas, disiplin kerja, kepuasan kerja dan motivasi karyawan sedangkan faktor eksternal meliputi: gaya kepemimpinan, lingkungan kerja, kompensasi dan sistem manajemen yang terdapat di perusahaan tersebut.

\section{b. Kompensasi}

Dessler (2007), kompensasi karyawan merupakan semua bentuk pembayaran atau hadiah yang diberikan kepada karyawan dan muncul dari pekerjaan mereka. Kompensasi ini mencakup tiga komponen yaitu: 
a. direct financial payment, seperti gaji, upah, bonus, insentif, dankomisi.

b. indirect payment, yaitu dalam bentuk tunjangan-tunjangan misalnya asuransi kesehatan, cuti kerja, tunjangan keluarga, program rekreasi, pensiun, koperasi simpan pinjam, transport dan sebagainya.

imbalan nonfinansial, yaitu hal-hal yang sulit untuk dikuantifikasi seperti halnya jam kerja yang sangat fleksibel, tugas dan pekerjaan yang mampu memberikan tantangan, dan fasilitas kantor yang dirasa bergengsi.

\section{e. Motivasi}

Wahjosumijo (1984), motivasi merupakan suatu proses psikologis yang mampu mencerminkan suatu interaksi antara sikap, persepsi, kebutuhan, dan keputusan yang dapat terjadi pada diri seseorang itu sendiri yang disebut intrinsic dan extrinsic. Vroom, (dalam Gisbon, 1984), mendefinisikan motivasi sebagai suatu proses yang menentukan pilihan antara beberapa alternatif dari kegiatan sukarela.

\section{f. Penelitian Terdahulu}

Penelitian yang dilakukan Ririvega Kasenda (2013) dengan judul Kompensasi dan Motivasi Pengaruhnya
Terhadap Kinerja Karyawan Pada PT. Bangun Wenang Beverages Company Manado. Bertujuan untuk mengetahui pengaruh variabel kompensasi perusahaan yang diberikan dan motivasi karyawan terhadap kinerjanya dan metode yang digunakan adalah kuantitatif. Hasil penelitianya adalah salah satu tujuan pemberian kompensasi adalahmotivasi. Jika balas jasa perusahaan kepada karyawan yang diberikan cukup besar, manajer akan mudah memotivasi bawahannya. Motivasi merupakan suatu proses yang berperan pada intensitas, arah, dan lama berlangsungnya upaya individu ke arah pencapaian sasaran. Sehingga apabila seorang karyawan merasa dan menganggap bahwa kompensasi yang diberikan oleh perusahaan sesuai dengan yang diharapkan karyawan, maka dapat memotivasi karyawan untuk meningkatkan kinerjanya.

Satria Tahir, 2013. Dengan judul Analisis Kinerja Karyawan pada PT. Sinar Galesong Pratama (SGP) Cabang Gorontalo. Bertujuan untuk mengetahui Analisis Kinerja Karyawan Pada PT. Sinar Galesong Pratama (SGP) CabangGorontalo dan metode yang digunakan adalah kualitatif. Hasil penelitianya adalah kinerja karyawan yang bekerja pada 
PT. Sinar Galesong Pratama (SGP) di

Cabang kota Gorontalo belum maksimal, yaitu dalam hal disiplin, motivasi dan prestasikerja.

\section{METODE}

\section{a. Design Penelitian}

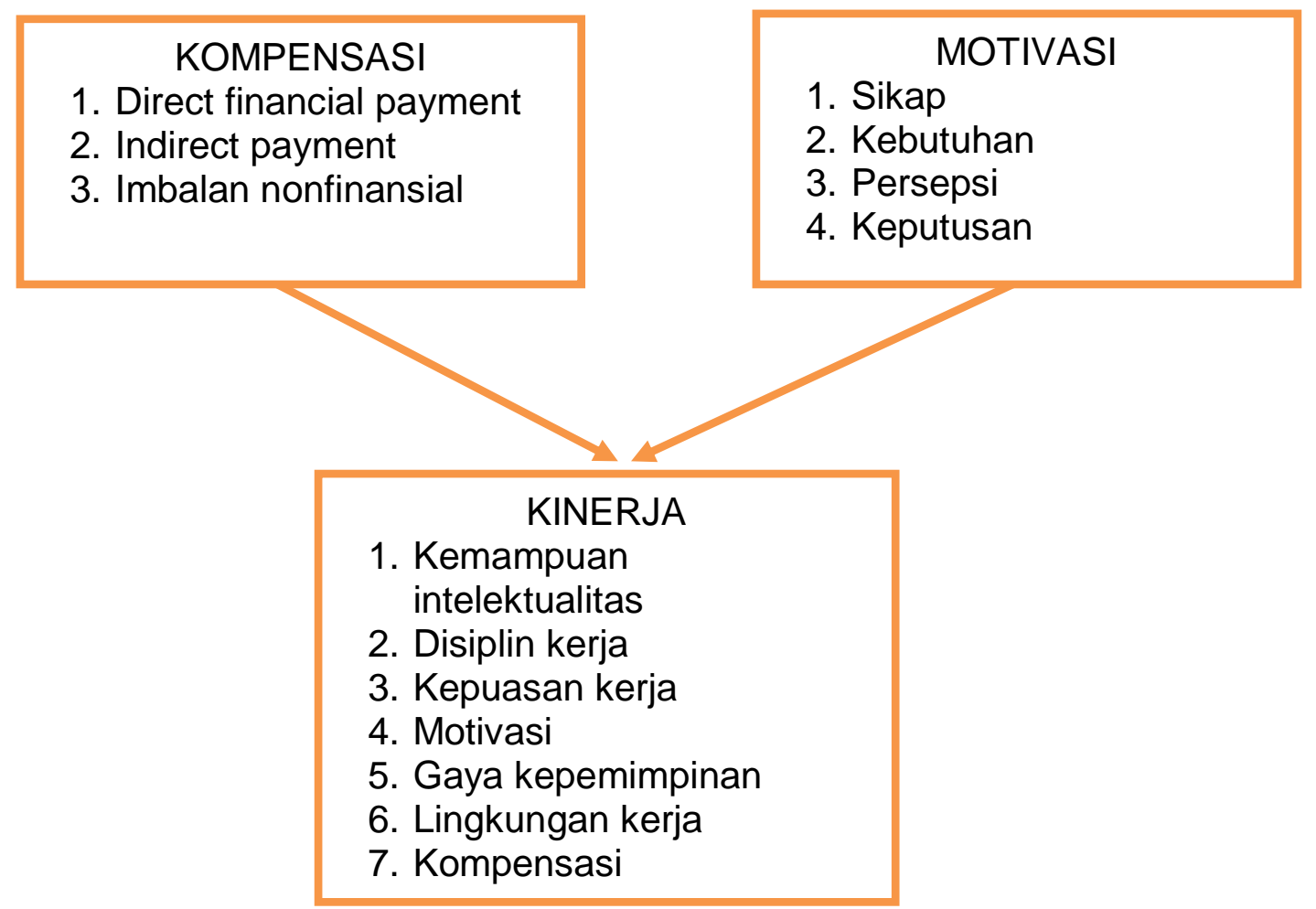

\section{b. Jenis Penelitian}

Penelitian ini menggunakan pendekatan deskriptif analistis, dengan memfokuskan pada kajian tentang kinerja karyawan melalui kompensasi karyawan dan motivasi karyawan. Adapaun metode ini merupakan penelitian yang bersifat kualitatif yaitu : prosedur pencatatan untuk menggambarkan atau melukiskan keadaan objek yang diteliti berdasarkan fakta yang ada. Penelitian kualitatif menuturkan dan menafsirkan data dengan situasi yang terjadi, sikap dan pandangan dalam masyarakat (Ahire \& Golhar 1996) adapun tujuan yang dicapai dari penggunaan teknik analis deskriptif yaitu : suatu penelitian dengan cara menggambarkan secara sistematik, factual, dan akurat dari fakta peristiwa yang ada.

Tabel 2. Variabel, Indikator dan pengukuran

\begin{tabular}{|l|l|l|}
\hline Variabel & Indikator & Pengukuran \\
\hline
\end{tabular}




\begin{tabular}{|c|c|c|}
\hline Kinerja Karyawan & $\begin{array}{l}\text { 1. Kemampuan } \\
\text { intelektualitas } \\
\text { 2. Disiplin kerja } \\
\text { 3. Kepuasan kerja } \\
\text { 4. Motivasi } \\
\text { 5. Gaya kepemimpinan } \\
\text { 6. Lingkungan kerja } \\
\text { 7. Kompensasi } \\
\text { 8. Sistem manajemen }\end{array}$ & $\begin{array}{l}\text { Wawancara yang } \\
\text { mendalam (deep } \\
\text { interview) } \\
\text { Dengan Manajer }\end{array}$ \\
\hline Kompensasi & $\begin{array}{l}\text { 1. Direct financial payment } \\
\text { 2. Indirect payment } \\
\text { 3. Imbalan nonfinansial }\end{array}$ & $\begin{array}{c}\text { Wawancara yang } \\
\text { mendalam (deep } \\
\text { interview) } \\
\text { Dengan Karyawan }\end{array}$ \\
\hline Motivasi & $\begin{array}{l}\text { 1. Sikap } \\
\text { 2. Kebutuhan } \\
\text { 3. Persepsi } \\
\text { 4. Keputusan }\end{array}$ & $\begin{array}{l}\text { Wawancara yang } \\
\text { mendalam (deep } \\
\text { interview) } \\
\text { Dengan Karyawan }\end{array}$ \\
\hline
\end{tabular}

Sumber : Nugroho 2015

\section{c. Lokasi Penelitian}

Dalam Penelitian ini, objek penelitian pada karyawan PT. Reycom Dokumen Solusiyang beralamat Bizpark Commercial Estate Blok A5 No.7 Jl. Raya Bekasi KM.21 Pulo gadung Jakarta Timur. Adapun waktu yang dimanfaatkan untuk melakukan pengumpulan data diperlukan adalah 2 bulan, yaitu bulan Juli sampai bulan Agustus.

\section{d. Infroman Peneliatian}

Penelitian kualitatif tidak menggunakan istilah populasi, karena penelitian kualitatif berdasarkan dari kasus tertentu yang ada pada situasi tertentu dan hasil kajiannya tidak diberlakukan ke populasi, tetapi di transfer ke tempat lain pada situasi sosial yang memiliki kesamaan dengan situasi sosial pada kasus yang dipelajari.
Sampel dalam sebuah penelitian kualitatif bukan dinamakan responden, akan tetapi sebagai narasumber, atau partisipan, informan, teman dan guru dalam penelitian. (Sugiyono, 2008). Informan dalam penelitian ini adalah pelaku dalam industri ekstraktif itu sendiri.

\section{e. Prosedur Standar Operasional Pengumpulan Data}

Metode yang digunakan dalam sebuah pengolahan data dibagi menjadi beberapa tahapan sehingga membentuk suatu kerangka yang sistematis. Adapun tahapan tersebut adalah :

1. Tahapan Sebelum Kelapangan

Meliputi kegiatan penentuan fokus, penyesuaian paradigm dengan teori, penjajakan alat peneliti, mencakup observasi lapangan dan permohonan ijin kepada subyek yang diteliti, konsultasi 
fakus penelitian, penyusunan usulan penelitian.

2. Tahap Pekerjaan Lapangan

Data tersebut diperoleh dengan observasi, wawancara dan dokumentasi pada narasumber yang ada di Industri Ekstraktif.

3. Tahap Analisis Data

Meliputi analisis data baik yang diperoleh melalui observasi, dokumen ataupun wawancara yang mendalam dengan narasumber yang ada. Kemudian akan dilakukan penafsiran data sesuai dengan konteks permasalahan yang diteliti, selanjutnya melakukan pengecekan keabsahan data dengan cara mengecek sumber data yang didapat dari metode perolehan data. Sehingga data benar-benar valid sebagai dasar dan bahan untuk memberikan makna data yang merupakan proses penentuan dalam memahami konteks penelitian yang sedang diteliti.

4. Tahap Penulisan Jurnal

Meliputi kegiatan penyusunan hasil dari penelitian dan semua rangkaian kegiatan pengumpulan data sampai pemberian makna pada data.

\section{f. Sumber Data}

Sumber data dalam penelitian merupakan faktor penting yang menjadi sumber pertimbangan dalam penentuan metode pengumpulan data, disamping jenis data yang telah dibahas sebelumnya. Sumber data penelitian terdiri dari:

\section{Sumber Data Primer}

Sumber data primer adalah sumber data suatu penelitian yang diperoleh melalui wawancara secara langsung dari sumber asli atau responden (Pimpinan, Admin Sales serta Staff) untuk memperoleh data atau informasi yang akurat.

\section{Sumber Data Sekunder}

Sumber data yang sekunder yaitu sebagai bahan pendukung untuk memudahkan penelitian ini. Untuk itu calon peneliti menggunakan buku-buku, literatur dan dokumenlain yang relevan dengan masalah yang di teliti.

\section{g. Keabsahan Data}

Keseluruhan data yang digunakan dalam penelitian ini bersumber dari objek penelitian pelaku yang terlibat dalam PT. Reycom Dokumen Solusi. Data didapatkan lewat pengamatan di lapangan, wawancara langsung, melakukan diskusi dengan pihak terkait, kemudian dokumentasi yang langsung diperoleh dari objek peneltian.

\section{h. Teknik Analis Data}

Teknik analisis data yang digunakan dalam penelitian ini adalah analisis 
deskriptif kualitatif. Analisis deskriptif

kualitatif yaitu prosedur pencatatan yang dilakukan untuk menggambarkan atau melukiskan keadaan objek yang diteliti berdasarkan fakta yang ada. Adapun tujuan yang ingin dicapai dari penggunaan teknik analisis deskriptif kualitatif tersebut yaitu dengan mengupayakan suatu penelitian dengan cara menggambarkan secara sistematis, terstruktur, faktual, dan akurat dari suatu fakta akan suatu peristiwa.

\section{i. Deskripsi Informan}

Tabel 3. Informan

\begin{tabular}{|l|l|l|}
\hline \multicolumn{1}{|c|}{ Jenis Jabatan } & \multicolumn{1}{|c|}{ Informan } & \multicolumn{1}{c|}{ Tempat/Alamat } \\
\hline Manajer Produksi & Informan 1 & PT. Reycom Dokumen Solusi \\
\hline Supervisor Produksi & Informan 2 & PT. Reycom Dokumen Solusi \\
\hline Karyawan & Informan 3 & PT. Reycom Dokumen Solusi \\
\hline
\end{tabular}

Sumber Data Primer yang diolah, 2015

HASIL

\section{a. Kinerja}

Peranan karyawan sangatlah penting bagi perusahaan guna menunjang keberhasilan setiap perusahaan terutama perusahaan yang bergerak di sektor jasa. Alasannya karena karyawan mampu mempengaruhi persepsi pelanggan, karyawan merupakan bagian dari jasa itu sendiri, sehingga pelanggan beranggapan, bahwa karyawan yang berfungsi sebagai komunikator sekaligus perwakilan dari citra perusahaan. Karyawan berperan aktif sebagai human attribute yang berfungsi sebagai pemasar yang mampu mempengaruhi calon pelanggan, dan dituntut mampu memuaskan kebutuhan dan keinginan pelanggan.Pertumbuhan akan semakin pesat terjadi pada produk layanan yang bersifat memberikan kepuasan kepada calon pelanggan atau pelanggan tetap di PT. Reycom Dokumen Solusi.

Disamping itu penilaian kinerja karyawan perlu diperhatikan dan dilihat dari indikator kinerja, antara lain :

1. Kemampuan intelektualitas

Kemampuan Intelektual dari karyawan PT. Reycom Dokumen Solusi sudah memadahi sesuai bidangnya, hanya saja ada beberapa sdm yang penempatanya belum sesuai kompetensi yang dimiliki yang mampu mampu menurunkan kinerja karyawan karena memerlukan waktu untuk belajar dan beradaptasi.

2. Disiplin kerja 
Tingkat kehadiran dan ketepatan waktu belum bisa dimanfaatkan secara maksimal oleh karyawan pada PT. Reycom Dokumen Solusi. Ini bisa dilihat dari jam pagi dilaksanakan karyawan menggunakan fingerprint sehingga dapat meminimalisir tingkat keterlambatan.

\section{Target Produksi}

Target Produksi dapat selesai sesuai jadwal tergantung dari tim produksi itu sendiri dan tingkat kesulitan project produksi yang menyesuaikan permintaan konsumen.

\section{Kepuasan kerja}

Karyawan belum merasa puas dengan pekerjaanya di PT. Reycom Dokumen Solusi dikarenakan belum mampu memberikan dampak yang signifikan terhadap pemenuhan kebutuhan hidup yang lebih layak dari hasil kerja diperusahaan tersebut.

\section{Motivasi}

Motivasi karyawan selama bekerja ialah untuk memenuhi kebutuhan hidup minimal dan mendapatkan pekerjaan yang lebih layak, sehinggamasih banyak karyawan tertarik untuk mengikuti seleksi rekrutmen karyawan baru diperusahaan lain.

6. Gaya kepemimpinan
Manajer diperusahaan tersebut sangat dihormati oleh karyawanya karena mampu memberikan arahan yang tepat, mengerti keadaan karyawanya dan mampu memberikan motivasi untuk bekerja keras guna menghasilkan produk sesuai standar perusahaan.

\section{Lingkungan kerja}

Lingkungan kerja yang sehat sangat mempengaruhi kinerja karyawanuntuk menghasilkan produk sesuai target dan satndar perusahaan.

8. Kompensasi

Kompensasi yang diberikan perusahaan kepada karyawan masih belum ada.

9. Sistem manajemen

Sistem manajemen yang belum tersistem secara maksimal belum mampu memberikan efek yang signifikan terhadap kinerja karyawan di PT. Reycome Dokumen Solusi.

\section{b. Motivasi}

Motivasi merupakan kondisi yang menggerakkan diri karyawan yang terarah dan tanpa paksaan untuk mencapai tujuan organisasi. Setiap karyawan yang menghadapi situasi kerja, karyawan tersebut harus siap mental dan mampu memahami tujuan utama dan target kerja yang akan dicapai sehingga karyawan mampu memanfaatkan dan menciptakan situasi 
kerja. Sesuai dengan hasil penelitian, ada beberapa faktor-faktor yang dapat memotivasi kerja karyawan yaitu berupa motivasi financial seperti pemberian bonus/insentif belum mampu meningkatkan kinerja karyawan, sedangkan penghargaan, kenaikan pangkat dan pujian kepada karyawan sudah mampu meningkatkan kinerja karyawan. Salah satu dari faktor motivasi kerja karyawan yang merupakan masalah dari PT. Reycom Dokumen Solusi yaitu persoalan insentif.

\section{c. Kompensasi}

1. direct financial payment

Karyawan sudah merasa cukup dengan gaji yang diberikan oleh perusahaan yang menurut narasumber sudah sesuai UMR, hanya saja belum adanya bonus, insentif dan komisi.

2. indirect payment
Belum adanya tunjangan kesehatan, tunjangan keluarga, pensiun dan transport yang dibayarkan perusahaan kepada karyawan dapat mempengaruhi kinerja karyawan diperusahaan. Akan tetapi cuti kerja yang lebih dimudahkan dapat membuat karyawan merasa senang sehingga dapat meningkatkan kinerja karyawan.

3. imbalan nonfinansial

Jam kerja yang feksibel membantu pekerjaan karyawan dalam melaksanakan tugasnya, project baru di produksi selalu ada kerumitanya sendiri. Karyawan merasa hal baru sangat menantang bagi meraka untuk melaksanakan tugas dan pekerjaan mereka. Hanya saja fasilitas kantor belum bergengsi atau menjadi kebanggan dalam melaksanakan pekerjaan dan tugasnya.

Tabel 4. Perbandingan Hasil Variabel Penelitian

\begin{tabular}{|l|l|l|}
\hline \multicolumn{1}{|c|}{ Kinerja } & \multicolumn{1}{|c|}{ Kompensasi } & \multicolumn{1}{c|}{ Motivasi } \\
\hline $\begin{array}{l}\text { Gaya Kepemimpinan dan } \\
\text { Lingkungan Kerja } \\
\begin{array}{l}\text { Perusahaan mampu } \\
\text { meningkatkan kinerja } \\
\text { Karyawan. }\end{array}\end{array}$ & $\begin{array}{l}\text { Gaji, cuti kerja dan jam } \\
\text { kerja yang fleksibel mampu } \\
\text { meningktakan kinerja } \\
\text { karyawan. }\end{array}$ & $\begin{array}{l}\text { Penghargaan, kenaikan } \\
\text { pangkat dan pujian mampu } \\
\text { meningkatkan kinerja } \\
\text { karyawan. } \\
\text { kepada karyawan }\end{array}$ \\
\hline $\begin{array}{l}\text { Penempatan SDM, } \\
\text { disiplin kerja, target } \\
\text { produksi, kepuasan kerja, } \\
\text { motivasi, kompensasi dan } \\
\text { sistem manajemen belum } \\
\text { mampu meningkatkan } \\
\text { kinerja karyawan }\end{array}$ & $\begin{array}{l}\text { Bonus/insentif, tunjangan } \\
\text { kesehatan, tunjangan } \\
\text { keluarga, pensiun, transport } \\
\text { dan fasilitas kantor belum } \\
\text { mampu meningkatkan } \\
\text { kinerja karyawan. }\end{array}$ & $\begin{array}{l}\text { Bonus/insentif yang belum } \\
\text { ada, belum mampu } \\
\text { meningkatkan kinerja } \\
\text { karyawan. }\end{array}$ \\
\hline
\end{tabular}


d. Upaya-Upaya Yang Dilakukang Guna Meningkatkan Kinerja Karyawan pada PT. Reycom Dokumen Solusi

Beberapa langkah yang dapat ditempuh guna meningkatkan kinerja karyawan pada PT. Reycom Dokumen Solusi adalah sebagai berikut:

a. Bimbingan dan Pengarahan

Bimbingan dan pengarahan adalah upaya pemecahan masalah dengan karyawan dalam bidang-bidang tertentu, dengan maksud membantu para karyawan agard alam melaksanakan kinerjanya dapat berjalan dengan baik serta mampu menangani masalah-masalah dengan tuntas.

b. Latihan dan Pengembangan

Karyawan

Latihan dan pengembangan karyawan diberikan melalui berbagai hal. Melalui latihan tertentu maka para karyawan akan mendapatkan pengalaman kerja dalam bidang tertentu. Latihan merupakan cara untuk meningkatkan keterampilan dan akan menambah pengalaman kerja para karyawan, sehingga akan membawa perubahan dan peningkatan dalam sistem kerja karyawan. Dengan demikian, latihan dan pengembangan kompetensi karyawan, dimana karyawan yang tersebar dalam beberapa bidang diharapkan memiliki kelebihan kecakapan dan keterampilan dasar yang dibutuhkan.

c. Pendisiplinan terhadap aturan untuk mencapai efisiensi dan efektifitas organisasi yang tinggi.

Proses pendisiplinan atau penerapan aturan yang ketat kepada para karyawan harus bisadilakukan oleh pimpinan dalam hal ini adalah pimpinan PT. Reycom Dokumen Solusi agar pencapaian tujuan organisasi/perusahaan bisa lebih efektif dan efisien. Proses pendisiplinan tersebut bisa dilakukan dengan cara pimpinan memberikan contoh yang positif kepada karyawannya, seperti datang dan pulang kerja sesuai dengan aturan yang ditetapkan, menyelesaikan pekerjaan dengan tepat waktu, menerima segala keluhan dan masukan yang disampaikan olehkaryawannya dan berusaha untuk bisa mengayomikaryawan yang ada. Hal ini sesuai pendapat yang disampaikan oleh Bass et al (2003) yang menyatakan bahwa disiplin, motivasi, dan kompensasi merupakan faktor penting yang 
dapat menentukan kinerja karyawan dan kemampuan organisasi beradaptasi dengan lingkungan. Oleh sebab itu, disiplin merupakan salah satu komponen yang penting dalam membangun sebuah perusahaan yang besar.

\section{PEMBAHASAN}

Perusahaan dalam pencapain tujuan adakalanya sesuai apa yang diharapkan, akan tetapi adakalanya tidak sesuai harapan dengan hasil yang kurang optimal. hal ini tergantung dari motivasi dari masingmasing karyawan untuk melaksanakan tugasnya dengan baik dalam kegiatan pekerjaan kayawan di perusahaan. Agar pelaksanaan kegiatan perusahaan berjalan dengan baik diperlukanya kinerja karyawan yang intens terhadap penyelenggara pekerjaanya. Rangkaian aktivitas di perusahaan mencakup perencanaan, pengorganisasian, pengarahan, pengawasan, pengendalian serta penyelenggaraan pekerjaan berdasarkan pembagian kerja masing-masing.

Karyawan adalah aset penting bagi perusahaan jasa, oleh karena kemampuan karyawan dalam elemen ini dapat mempengaruhi kepuasan pelanggan. Kinerja karyawan sangat menentukan bagaimana proses suatu pekerjaan dapat berjalan dengan baik guna mencapai tujuan perusahaan. Gaya kepemimpinan dan lingkungan kerja diperusahaan mampu meningkatkan kinerja karyawan dengan adanya pendekatan manajer dalam memberikan arahan dengan tepat, mengerti keadaan karyawanya dan memberikan motivasi jika ada karyawanya yang kurang bersemangat serta lingkungan sehat yang mendukung. Perusahaan yang sudah memberikan kompensasi kepada karyawanya diharapkan dapat memotivasi karyawan sehingga meningkatkan kinerjanya, sehingga tujuan perusahaan dapat tercapai.

Tujuan perusahaan adalah mampu menghasilkan produk atau jasa yang bermutu tinggi dan sekaligus mendapatkan keuntungan, hal ini dapat didukung jika kinerja karyawanya baik. Beberapa faktor yang dapat menurunkan kinerja karyawan yang perlu diperhatikan oleh perusahaan untuk mempertahankan mutu dan mendapatkan keuntungan sesuai tujuan perusahaan tersebut. Penempatan sdm sesuai komptensinya, target produksi yang tidak molor, kepuasan kerja karyawanya ada, disiplin kerja yang tinggi, motivasi karyawan utnuk bekerja tinggi, kompensasi yang diberikan sesuai harapan dan sistem manajemen perusahaan yang baik.

Perusahaan membutuhkan karyawan yang mampu bekerja dengan baik dan lebih cepat, sehingga diperlukan karyawan yang 
mempunyai kriteria tinggi. Berdasarkan hasil penelitian yang dilakukan, maka dapat disimpulkan faktor penting yang dapat menentukan kinerja karyawan dan kemampuan PT. Reycom Dokumen Solusi adalah SDM, target produksi, kepuasan kerja, motivasi, kompensasi, dan sistem manajemen.

\section{SIMPULAN DAN SARAN}

\section{a. Kesimpulan}

Berdasarkan deskripsi hasil dari penelitian dan pembahasan yang telah dikemukakan, maka peneliti dapat menarik kesimpulan yakni sebagai berikut :

1. Berdasarkan hasil dari penelitian dan wawancara yang dilakukan, maka penelitimenyimpulkan bahwa kinerja karyawan pada PT. Reycom Dokumen Solusi belum maksimal, yaitu dalam hal penenmpatan sdm sesuai keahlian, disiplin kerja, kepuasan kerja, sistem Manajemen, motivasi dan kompensasi.

2. Adapun upaya-upaya yang perlu dilakukan untuk meningkatkan kinerja karyawan pada PT. Reycom Dokumen Solusi yaitu :

a. Bimbingan dan pengarahan

b. Latihan dan pengembangan karyawan

c. Pendisiplinan terhadap aturan yang berlaku untuk mencapai efisiensi dan efektivitas organisasi yang tinggi

3. Hal yang masih kurang dan perlu ditingkatkan adalah pemberian penghargaan kepada prestasi yang berhasil dicapai oleh karyawan.

\section{b. Saran}

PT. Reycom Dokumen Solusi seharusnya lebih menekankan kepada apresiasi yang diberikan kepada para karyawan teruatama dalam penghargaan terhadap prestasi yang diperoleh dapat diberikan penghargaan yang stimpal. Hal ini dikarenakan dapat meningkatkan semangat dan produktivitas dari para karyawan supaya bisa menggunakan dengan baik apa yang sudah diperoleh dan tetap mempertahankan pencapaiannya. Hal ini juga bisa menguntungkan perusahaan karena dapat menambah kualitas hasil kinerja dari karyawan dan juga pastinya dapat meningkatkan motivasi dari karyawan lainnya supaya lebih berkreasi dan menunjukkan kerja yang optimal.

Selain itu, motivasi juga menjadi komponen yang penting dalam membangun kinerja yang baik. Wahjosumijo (1984), motivasi bisa diartikan sebagai suatu proses psikologis yang mencerminkan interaksi antara persepsi, sikap, kebutuhan, dan keputusan yang terjadi pada diri 
seseorang itu sendiri yang disebut intrinsic dan extrinsic. Untuk membangun motivasi yang baik maka dibutuhkan banyak faktor, diantaranya adalah dengan memberikan kompensasi yang sesuai. Hal ini disesuaikan dengan Dessler (2007) yang menyatakan bahwa kompensasi karyawan adalah semua bentuk pembayaran atau hadiah yang diberikan kepada karyawan dan muncul dari pekerjaan mereka.

\section{DAFTAR PUSTAKA}

Untuk buku/karangan ilmiah:

Anwar Prabu Mangkunegara. (2007). Manajemen Sumber Daya Manusia Perusahaan. Bandung: PT. Remaja Rosdakarya.

Bass et al. (2003). Dasar-dasar Motivasi.

Pionir Jaya: Bandung.

BPKP. (2000). Pengukuran Kinerja Suatu

Tinjauan Pada Instansi Pemerintah.

Jakarta: BPKP.

Dessler, Gary. (1997). Manajemen Sumber Daya Manusia Edisi Bahasa IndonesiaJilid $2 . \quad$ Jakarta: Prenhallindo.

Handoko, T. Hani. (2001). Manajemen Personalia dan Sumber Daya Manusia. Yogyakarta: BPFE

Hasibuan, Malayu SP. (2001). Manajemen Sumber Daya Manusia. Jakarta: BumiAksara.
Hasibuan, H. Malayu SP. (2005). Manajemen Sumber Daya Manusia. Jakarta: Bumi Aksara.

Miner, John, B. (1988). Organizational Behavior, Perfomance \& Productivity, State University: New York at Buffallo.

Sutrisno. (2007).Manajemen Keuangan, Ekonesia: Yogyakarta.

Sugiyono. (2008). Metode Penelitian Kuantitatif Kualitatif dan $R \& D$. Bandung: Alfabeta.

Wahjosumijo.(1984). Kepemimpinan dan Motivasi : Jakarta: Ghalia Indonesia.

Untukjurnalilmiah:

Ahire, Golhar, D.Y. (1996). Quality Management in Large Versus Small Firms. Journal of Small Business Management, 34, 1-13.

A. Soegihartono. (2012). Pengaruh Kepemimpinan Kepuasaan Kerja Terhadap Kinerja denagn Mediasi

Komitmen di PT Kayu Sakti Semarang. Jurnal Mitra Ekonomi dan Manajemen. 3. 123-139.

Koesoemaningsih, Rachmawati. (2013). Analisis Pengaruh Lingkungan Kerja Dan Upah Terhadap Kepuasan Kerja Karyawan Pada PT. Dadimulyo Sejati Geneng Kabupaten Ngawi. Media Soerjo. Jurnal Universitas Soerjo Ngawi 12. 1-26. 
Muslih, Basthoumi dkk. (2011). Analisis

Pengaruh Motivasi Terhadap

Kepuasan Kerja dan Kinerja

Pegawai di PT Sang Hyang Seri

(Persero) Regional III Malang.

Jurnal Aplikasi Manajemen,

Vol.10, No.4. 799-810.

Riansari, Sudiro, Rofiaty. (2012).

Pengaruh Kompensasi dan

Lingkungan Kerja terhadap

Kepuasan Kerja dan Kinerja

Karyawan (Studi Kasus PT Bank

Tabungan Pensiun Nasional,Tbk

Cabang Malang). Jurnal Aplikasi

Manajemen. Volume 10. Nomor 4.

Ririvega Kasenda. (2013) dengan judul

Kompensasi Dan Motivasi

Pengaruhnya Terhadap Kinerja

Karyawan Pada PT. Bangun Wenang beverages company manado. Jurnal riset ekonomi, manajemen, bisnis dan akuntansi. 1, 853-859.

Satria Tahir.(2013). Analisis Kinerja

Karyawan pada PT. Sinar Galesong

Pratama (SGP)Cabang Gorontalo.

Jurnal KIM Ekonomi dan Bisnis:

Universitas Negeri Gorontalo.

Wibowo, Felicia Dewi. (2006) Analisis

Pengaruh Peran Kepemimpinan Dan

Pengembangan Karir Terhadap

Komitmen Organisasi Dalam

Meningkatkan Kinerja Karyawan

(Studi Kasus: PT. Bank Maspion

Indonesia Cabang Semarang). 